\title{
Temperature efficiency of heat exchangers in air handling units
}

Piotr MICHALAK, Stanisław GRYGIERCZYK

DOI: 10.30464/jmee.2019.3.3.267

Cite this article as:

Michalak P., Grygierczyk S. Temperature efficiency of heat exchangers in air handling units. Journal of Mechanical and Energy Engineering, Vol. 3(43), No. 3, 2019, pp. 267-272.

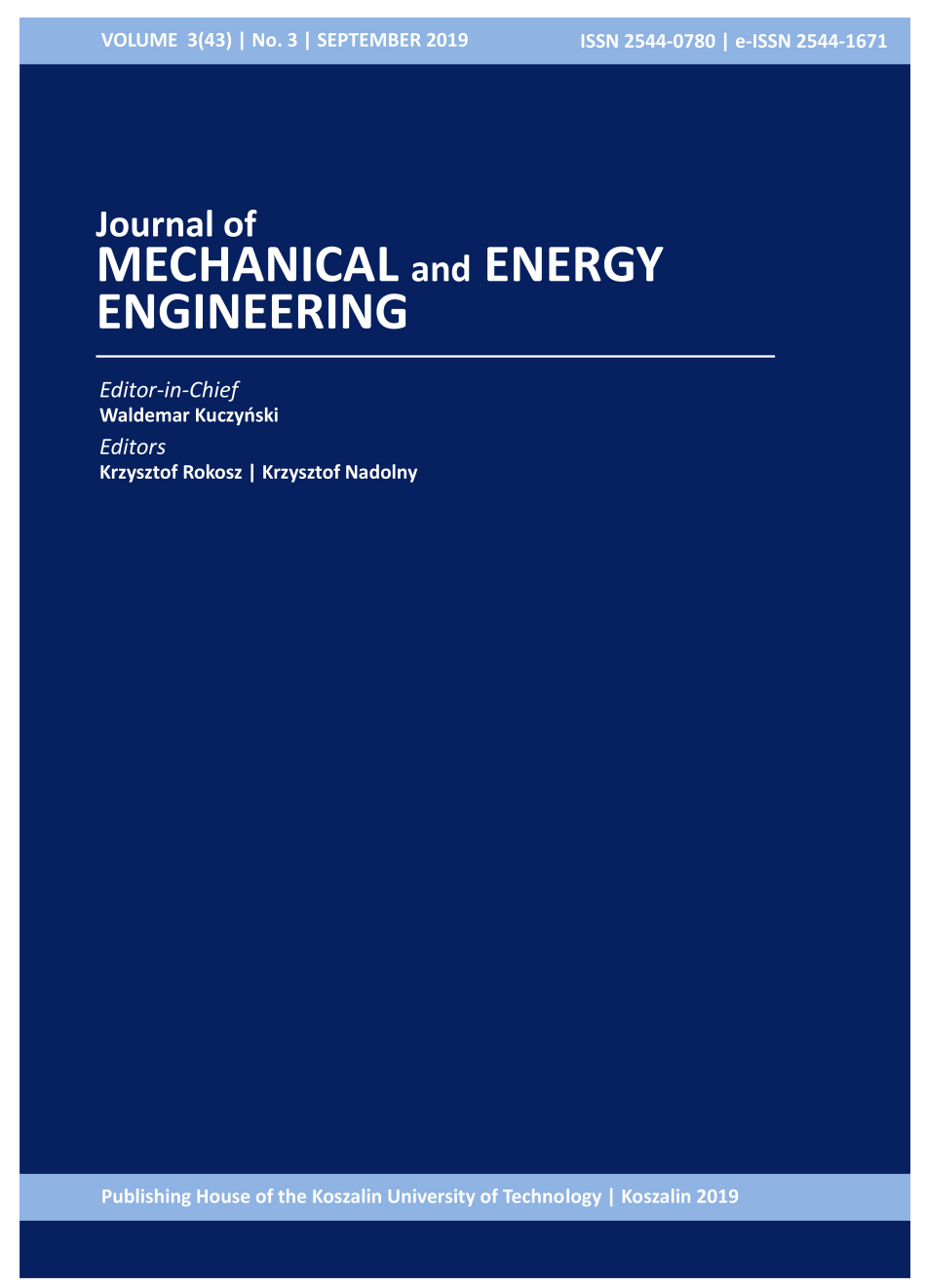

Journal of Mechanical and Energy

Engineering

Website: jmee.tu.koszalin.pl

ISSN (Print): 2544-0780

ISSN (Online): 2544-1671

Volume: 3(43)

Number: 3

Year: 2019

Pages: 267-272

Article Info:

Received 10 November 2019

Accepted 27 November 2019

\section{Open Access}

This article is distributed under the terms of the Creative Commons Attribution 4.0 (CC BY 4.0) International License (http://creativecommons.org/licenses/by/4.0/), which permits unrestricted use, distribution, and reproduction in any medium, provided you give appropriate credit to the original author(s) and the source, provide a link to the Creative Commons license, and indicate if changes were made. 


\title{
TEMPERATURE EFFICIENCY OF HEAT EXCHANGERS IN AIR HANDLING UNITS
}

\author{
Piotr MICHALAK ${ }^{1 *}$, Stanisław GRYGIERCZYK ${ }^{2}$ \\ ${ }^{1 *}$ Faculty of Mechanical Engineering and Robotics, Department of Power Systems and Environmental \\ Protection Facilities, AGH University of Science and Technology, Mickiewicza 30, 30-059 Kraków, Poland, \\ e-mail: pmichal@agh.edu.pl \\ ${ }^{2}$ Science and Technology Park Euro-Centre, Katowice, e-mail: s.grygierczyk@euro-centrum.com.pl
}

(Received 10 November 2019, Accepted 27 November 2019)

\begin{abstract}
In order to reduce ventilation heat loss and improve energy efficiency of low-energy buildings air-handling units (AHUs) with heat recovery are used. The article presents results of surveys performed in a passive building located in Katowice concerning the temperature efficiency of heat and cold recovery of two selected AHUs, with different heat exchangers. For this purpose the measurement data from the Building Management System (BMS) for the period 1.08.2015-31.07.2016 were used. The first unit was equipped with a rotary heat exchanger. Its average annual temperature efficiency of heat recovery was $47.2 \%$ annually. The efficiency of cold recovery amounted 52.9\% on average for the warm half year. The second unit had a cross-flow exchanger. The average annual temperature efficiency of heat recovery in this device was $80.1 \%$. The efficiency of cold recovery amounted $57.2 \%$ on average for the warm half year. Additional remarks concerning the temperature measurement in analysed units were also given.
\end{abstract}

Keywords: ventilation, heat recovery, rotary heat exchanger, cross-flow heat exchanger, temperature efficiency, PN-EN 308

\section{INTRODUCTION}

Buildings are responsible for about $40 \%$ of the energy consumption in European countries. Thus, the energy efficiency has become very important for buildings' designers and owners [1-3].

The use of heat recovery from exhaust air in mechanical ventilation systems reduces the energy use for space heating and cooling in buildings [4-5]. The basic element of such a system is an air handling unit (AHU) composed of two fans (exhaust and supply) and a heat exchanger. Cross-flow, counter-current and rotary heat exchangers are used [6-11]. Proper selection and operation of these devices have great impact on operating costs and on thermal comfort in buildings. Therefore, ongoing control of installed systems is also an important issue.

The article presents an analysis of the work of two AHUs in an office building. They were with rotary and cross-flow heat exchangers, respectively. The temperature efficiency of heat and cold recovery of both devices was determined. Also selected waveforms of the ventilation airflows and temperatures at characteristic points of this installation were presented, as well as unusual situations met during exploitation were discussed.

\section{VENTILATION SYSTEMS}

\subsection{Analyzed building}

The analyzed ventilation system is installed in an office building that fulfils standards defined by the National Fund for Environmental Protection and Water Management for passive buildings [12]. It has a compact structure and a large number of energy efficient windows to utilize solar gains. The floor radiant system supplied from heat pumps is used to cover the heating/cooling demand of the building. Cooling aggregates as well as heaters and coolers in the AHUs work as peak sources. Five independent AHUs work in the building [13]. Four of them are with rotary heat exchangers and one with a cross-flow heat exchanger. The heating, ventilation and air conditioning (HVAC) system is controlled by the BMS automation system. 
Construction of the building and its HVAC system were described in [14]. The work of the ventilation system with particular emphasis on the control and operation of NW1-NW3 AHUs was presented in [13]. The analysis of the temperature efficiency of the NW3 unit with a rotary heat exchanger was shown in [15].

This paper presents the analysis of the NW4 and NW5 units with the rotary and cross-flow heat exchangers, respectively. The study is based on the measurement data from the BMS system in the form of hourly values for the period from 1.08.2015 to 31.07.2016.

\subsection{The NW4 system}

The NW4 air handling unit consists of (Fig. 1) the exhaust fan (1), rotary heat exchanger (2), air filters (3), supply fan (4) as well as the heater (5) and cooler (6) used for temporary heating or cooling of air supplied to the room. Its capacity is $7800 \mathrm{~m}^{3} / \mathrm{h}$ and $7880 \mathrm{~m}^{3} / \mathrm{h}$ for supply and exhaust air, respectively.

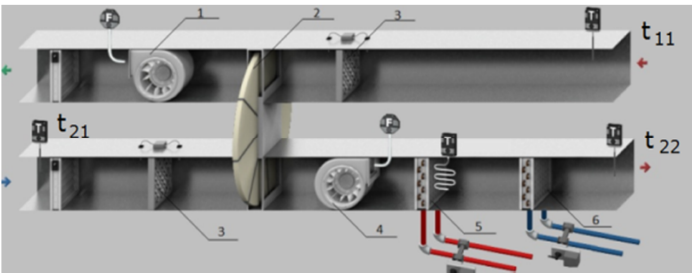

Fig. 1. The schematic view of the NW4 air handling unit

The control schedule of all AHUs is based on the working hours of companies located in the building. Typically the NW4 system is switched on at midnight and the supply air flow has the initial value of 4000 $\mathrm{m}^{3} / \mathrm{h}$. It is then increased to $7000 \mathrm{~m}^{3} / \mathrm{h}$ at $4: 00$ and remains unchanged until 17:00 when it is halved for another hour and then it is turned off (Fig. 2).

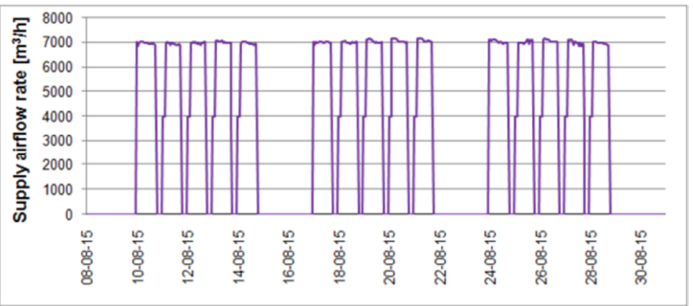

Fig. 2. The supply airflow rate of the NW4 unit in the 8.08.15-30.08.15 period

This cycle is repeated on each working day. On non-working days the ventilation system is switched off. In the winter months there may be changes in the control schedule of the system to reduce ventilation loss during the days with very low ambient temperatures.

In the analyzed period there were individual declines and returns of the airflow rate to the set value. They appeared due to maintenance works or performed tests. The second situation took place between 8.06.2016 and 15.06.2016 when the installation was operating continuously (Fig. 3).

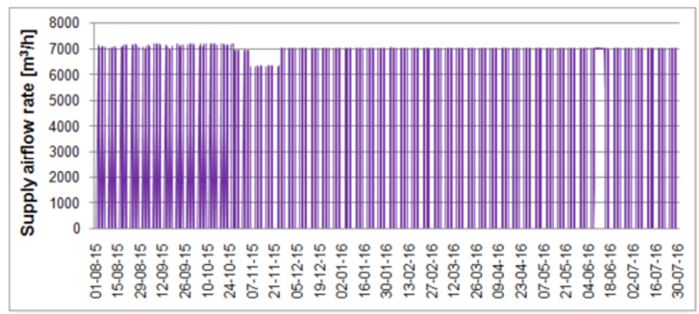

Fig. 3. The supply airflow rate of the NW4 unit in the 1.08.15-30.07.16 period

\subsection{The NW5 system}

This AHU differs from the previous one with the kind of the installed heat exchanger (Fig. 4), i.e. the cross-flow exchanger (2). Other components are the same as in Fig. 1. This solution is cheaper and was chosen here because this unit supplies with fresh air a much smaller number of rooms, mainly sanitary and utility rooms.

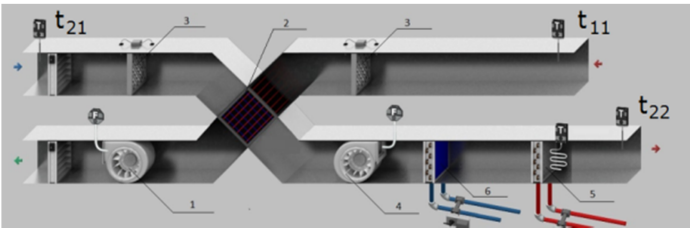

Fig. 4. The schematic view of the NW5 air handling unit

The NW5 unit operates in a similar manner as the previous one. Until 24.11 .15 the maximum supply airflow rate was $4700 \mathrm{~m}^{3} / \mathrm{h}$. Then it was set at 5000 $\mathrm{m}^{3} / \mathrm{h}$ (Fig. 5). During the analyzed period only a few short disruptions in this unit operation were noticed.

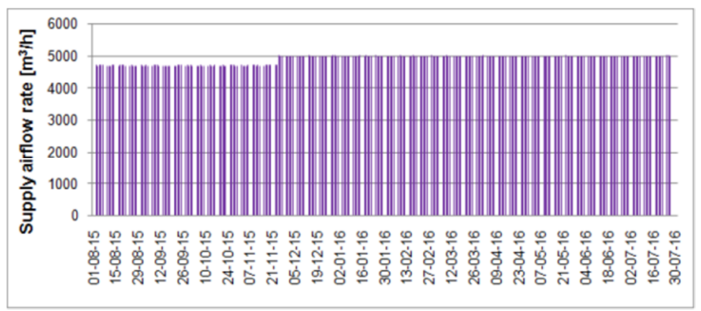

Fig. 5. The supply airflow rate of the NW5 unit in the 1.08.15-30.07.16 period

\section{ANALYSIS OF THE TEMPERATURE EFFICIENCY}

\subsection{PN-EN 308 standard}

The efficiency of a heat exchanger is defined in different ways, depending on heat balance elements taken into account. Sensible heat recovery is manifested by a change in an air temperature. Overall 
(energy) heat recovery includes sensible and latent heat recovery.

The PN-EN 308 standard [16] specifies methods to be used for laboratory testing of air-to-air heat recovery devices in buildings to obtain rating data and verify performance data given by manufacturers. The standard is applicable to three categories of heat exchangers: recuperators (I), exchangers with intermediary heat transfer medium (II) and regenerators (III). The methods prescribed are used for determining the external leakage, the internal leakage (I and II), the carry-over of exhaust air to supply air (III) and the temperature and humidity ratios.

To clarify an arrangement of sensors used in tests, the circuit diagram of the test bench was also given (Fig. 6) in the standard. Typically the temperature (t), pressure (p) and airflow rate (q) sensors are used in validation tests. The type and number of sensors used determines the range of performed measurements.

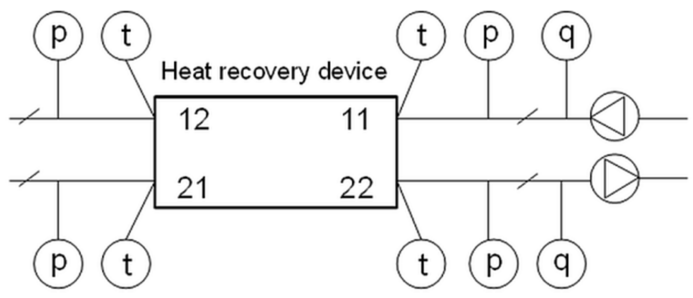

Fig. 6. The schematic diagram of the test stand to measure the temperature efficiency [16]

The temperature ratio (the exchanger's temperature efficiency), $\eta_{\mathrm{t}}$, is defined as [16]:

$$
\eta_{t}=\frac{t_{22}-t_{21}}{t_{11}-t_{21}}
$$

This expression refers only to the heat exchanger and not takes into account the energy used by the fans [17-18].

According to current Polish regulations, in buildings with mechanical ventilation, supply and exhaust ventilation or air-conditioning systems with the capacity over $500 \mathrm{~m}^{3} / \mathrm{h}$, the minimum temperature efficiency of heat recovery of $50 \%$ is required [19]. Manufacturers provide efficiency values of their devices tested in accordance with PN-EN 308. However, laboratory conditions differ from real operating conditions. For these reasons the results obtained from measurements taken in installations during normal operation are important to be presented.

During the heating season, as shown in Figure 1 and in Figure 4, fresh outside air at the temperature $t_{21}$ is delivered to a building by a supply fan. Then it flows through a heat exchanger where it is warmed up by indoor air at the temperature $t_{11}$, removed at the same time from a building by an exhaust fan, finally reaching the temperature $t_{22}$. It follows that under such conditions $t_{21}<t_{22}<t_{11}$.

However, in the summer period, when the ambient temperature is higher than the indoor air temperature, fresh outside air supplied to the building is cooled down in the heat exchanger by the removed internal air, and then $t_{21}>t_{22}>t_{11}$.

Also a lack of heat exchange may occur during the transitional period when $t_{21}=t_{11}$ [20].

In the analyzed building both heating and cooling modes were used. Thus, in the following sections of the paper the detailed analysis of efficiency for heating and cooling was presented.

\subsection{The NW4 unit}

The considered period from 1.08.2015 to 31.07.2016 covered a total of 8784 hours. This AHU worked for 4020 hours, what represented $45.8 \%$ of the period studied. This device also had a built-in heater and air cooler (Fig. 1) that were used during peak periods of heat and cold demand. Their operation influenced on the value of the measured temperature $\mathrm{t}_{22}$, therefore the time intervals when air heating or cooling was active were not taken into account. The arrangement of the temperature sensors in this AHU is shown in Figure 1 (marked with the "T" letter).

According to the measurement data the outside air temperature ranged from $-13.1^{\circ} \mathrm{C}$ on 4.01 .2016 at $6: 00$ to $34.1^{\circ} \mathrm{C}$ on 8.08 .2016 at $14: 00$.

The hourly temperature efficiency of heat recovery, $\eta_{t}$, determined from the Eq. (1) ranged from $1.4 \%$ on 4.09 .2015 at 3:00 to $99.0 \%$ on 23.11 .2015 at 17:00 (Fig. 7). The high value of $99 \%$ was the transient hourly value resulting from thermal dynamics of the building and its HVAC system.

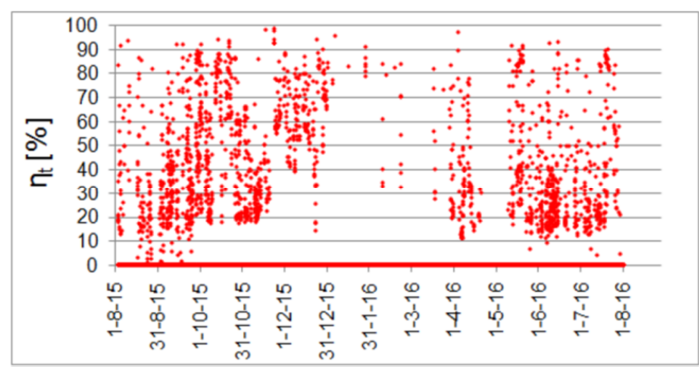

Fig. 7. The hourly efficiency of heat recovery

There was noticed a tendency to achieve a better efficiency for colder months when heat recovery was desired. The average monthly temperature efficiency of heat recovery was from $32.0 \%$ in June to $83.8 \%$ in January. For the cold half-year (X-III) it amounted $57.0 \%$. The average calculated for the whole year was $47.2 \%$. Wide variability of the obtained efficiency (Fig. 7) resulted from varying ambient and internal conditions and from the way the building is used. Low energy demand of the building for heating and cooling means its dependency on the weather conditions 
(especially solar irradiance) and internal heat gains coming from users, electronic equipment, etc.

Taking into account the summer period and comparing obtained results with the values found in the literature [21-26] it can be said that the results were satisfactory.

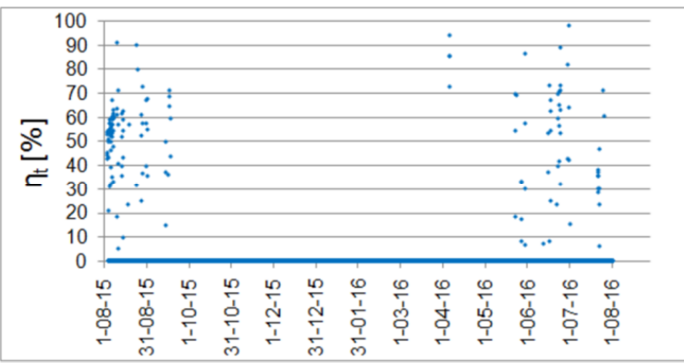

Fig. 8. The hourly efficiency of cold recovery

The efficiency of cold recovery was calculated for the warmer half year (IV-IX) because in cold months this mode of HVAC system operation was not used. It ranged from $5.3 \%$ on 8.08 .2015 at $8: 00$ to $98.1 \%$ on 30.06 .2015 at 17:00 (Fig. 8). The average monthly value of this efficiency ranged from $35.5 \%$ in July to $84.7 \%$ in April and amounted $52.9 \%$ on average for the warm half year. Comparison with other papers [27-30] also gave satisfying outcomes.

\subsection{The NW5 unit}

The calculation assumptions were the same as in the previous case. This unit worked for a total of 3068 hours, what represented $34.9 \%$ of the period studied.

The hourly temperature efficiency of heat recovery ranged from $7.7 \%$ on 2.09 .2015 at $6: 00$ to $99 \%$ on 9.10.2015 at 16:00 (Fig. 9). Further calculations were performed excluding the data for January. It was so because of the continuous work of the additional heater (see Fig. 4) during that month.

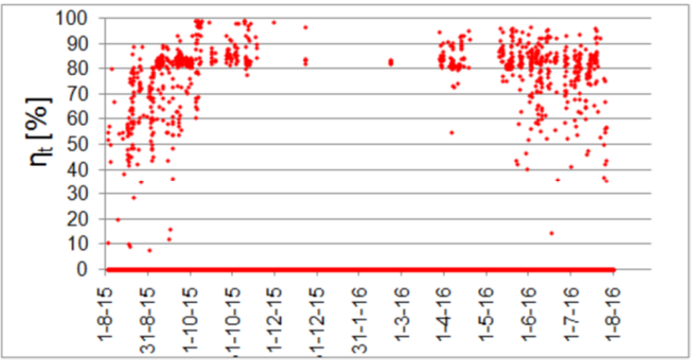

Fig. 9. The hourly efficiency of heat recovery

The average monthly temperature efficiency of heat recovery ranged from $60.3 \%$ in August to $87.2 \%$ in November. For the cold half-year (X-III) it amounted $85.1 \%$. The annual average was $80.1 \%$.

The efficiency of cold recovery was calculated for the warmer half year (IV-IX) because in cold months it was not used. It ranged from $6.3 \%$ on 27.05 .2015 at
14:00 to $98.9 \%$ on 24.06 .2015 at 16:00 (Fig. 10). The average monthly values of the $\eta_{t}$ were from $37.8 \%$ in April to $83.7 \%$ in September and amounted $57.2 \%$ on average for the warm half year.

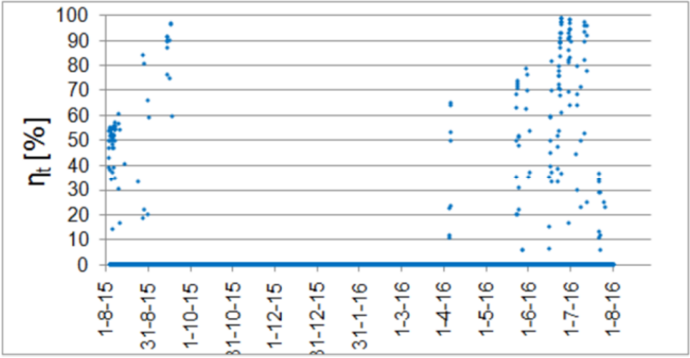

Fig. 10. The hourly efficiency of cold recovery

\subsection{Maintenance remarks}

Variability of external and internal air temperatures creates favourable or not favourable conditions for heat and cold recovery. Figure 11 shows temperature waveforms at the characteristic points of the NW4 unit and the supply ventilation airflow rate during the period from 1.08.2015 to 6.08.2015.

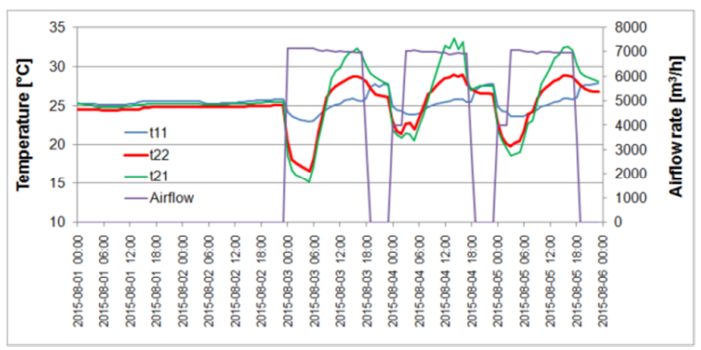

Fig. 11. The temperatures and airflow rate in the NW4 unit

During the first two days (1.08-2.08) all three temperatures were similar. These were non working days and the ventilation system was switched off. It would seem that the temperature $t_{21}$ should be equal to the ambient temperature. But the temperature sensor (see Fig. 1) was mounted inside a ventilation duct, near the air filter. The AHU was connected to the fresh air intake through the supply duct. When the AHU was switched off, still air in this duct warmed up to the temperature close to the temperature inside the building.

The situation changed at midnight 2/3.08.2015. The system started to deliver fresh air to the building and the $t_{21}$ sensor was cooled down by the flowing external air. Initially, fresh ambient air had a lower temperature $\left(t_{21}\right)$ than internal air removed from the building $\left(t_{11}\right)$. It meant that air supplied to the building was warmed up by exhaust air in the heat exchanger and heat recovery might have occurred even in summer. After some time, along with the increasing external air temperature, $t_{11}, t_{21}$ and $t_{22}$ became equal. Starting from this moment, the temperature of outside 
air supplied to the rooms $\left(t_{22}\right)$ began to rise above the temperature of exhausted air $\left(t_{11}\right)$. It resulted in heating of the building. This was an undesirable phenomenon, which additionally caused the cooler to switch on ((6) in Fig. 1). The reverse phenomenon, i.e. cooling of internal air by cold outside air, causing the heater to turn on, might take place in the winter. However, it should be remembered that the main goal of the ventilation system is to supply fresh air and remove used air. The energetic effect comes second.

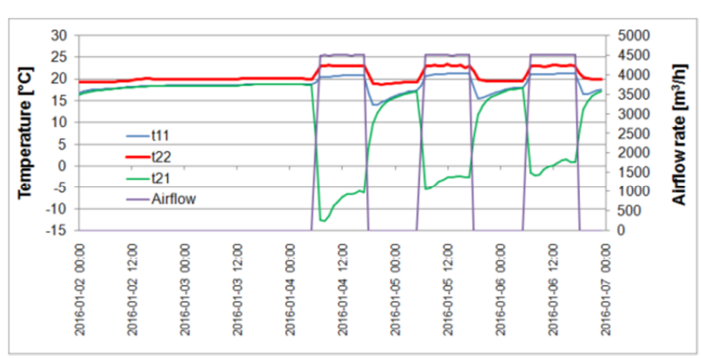

Fig. 12. The temperatures and airflow rate in the NW5 unit.

The aforementioned phenomenon of warming up the $t_{11}$ temperature sensor was particularly evident in the winter (Fig. 12). The temperature of this sensor decreased rapidly just after start of the AHU and then followed changes of the ambient air temperature.

\section{CONCLUSIONS}

The paper presents results of calculations of the temperature efficiency of two AHUs working in the passive office building. They have the rotary and cross-flow heat exchangers mounted in the NW4 and NW5 units, respectively.

For the NW4 unit the average annual temperature efficiency of heat recovery was $47.2 \%$ annually. The efficiency of cold recovery amounted $52.9 \%$ on average for the warm half year. The average annual temperature efficiency of heat recovery in the NW5 unit was $80.1 \%$. The efficiency of cold recovery amounted $57.2 \%$ on average for the warm half year.

Comparison of obtained results with other papers shown satisfactory values of calculated efficiencies for both considered ventilation units. However, in the previous study [15] the annual temperature efficiency of the rotary heat exchanger in the NW3 unit was $70.3 \%$ and $59.3 \%$ for heat and cold, respectively. It is difficult to diagnose the cause of these differences in the same building. The explanation of this situation can bring the long term analysis.

It also should be noted that a number of samples were rejected due to the active heater or cooler in the AHU. As a result, for heating, the total number of 1791 and 950 hourly measurement samples for the NW4 and NW5 units, respectively, was used. For cooling these numbers were significantly lower and amounted 148 and 186 for the NW4 and NW5 units, respectively. Because of that, it is advisable to increase the frequency of recording measurement data from 1 to e.g. 2 or 4 per hour.

The detailed analysis of temperatures and airflows waveforms revealed the need to thoroughly plan an arrangement of temperature sensors in HVAC systems. This is so because sensors' locations affect the measurement results and subsequent conclusions.

\section{Nomenclature}

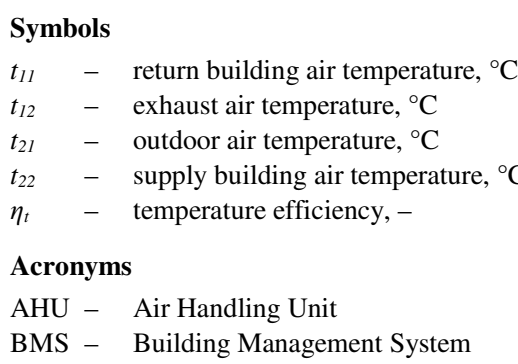

\section{References}

1. Życzyńska A., Cholewa T. (2015). The modifications to the requirements on energy savings and thermal insulation of buildings in Poland in the years 1974-2021. Budownictwo i Architektura, Vol. 14, No. 1, pp. 145154.

2. Szul T. (2017). The consumption of final energy for heating educational facilities located in rural areas. Journal of Research and Applications in Agricultural Engineering, Vol. 62, No. 1, pp. 171-175.

3. Sikora M., Siwek K. (2018). Energy audit of the residential building. Journal of Mechanical and Energy Engineering, Vol. 2(42), No. 4, pp. 317-328. DOI: 10.30464/jmee.2018.2.4. 317

4. Kostka M., Szulgowska-Zgrzywa M. (2017). Changeover natural and mechanical ventilation system energy consumption in single-family buildings. In: ASEE17, E3S Web of Conferences, Vol. 22, 00086. DOI: 10.1051/e3sconf/20172200086

5. Pietkun-Greber I., Suszanowicz D. (2018). The consequences of the inappropriate use of ventilation systems operating in indoor swimming pool conditions analysis. In: INFRAEKO 2018, E3S Web of Conferences, Vol. 45, 00064 . https://doi.org/10.1051/e3sconf/20184500064

6. Mardiana-Idayua A., Riffat S.B. (2012). Review on heat recovery technologies for building applications. Renewable and Sustainable Energy Reviews, Vol. 16, pp. 1241-1255. DOI: 10.1016/j.rser.2011.09.026

7. Enteria N., Yoshino H., Mochida A. (2013). Review of the advances in open-cycle absorption air-conditioning systems. Renewable and Sustainable Energy Reviews, Vol. 28, pp. 265-289. DOI: 10.1016/j.rser.2013.07.012

8. Cuce P.M., Riffat S. (2015). A comprehensive review of heat recovery systems for building applications. Renewable and Sustainable Energy Reviews, Vol. 47, pp. 665-682. https://doi.org/10.1016/j.rser.2015.03.087

9. Zeng C., Liu S., Shukla A. (2017). A review on the airto-air heat and mass exchanger technologies for building applications. Renewable and Sustainable Energy Reviews, Vol. 75, pp.753-774. https://doi.org/10.1016/j.rser.2016.11.052

10. Kostka M. (2017). Hybrid ventilation in residential buildings - the proposal of research for the Polish 
climatic conditions. In: EKO-DOK 2017, E3S Web of Conferences, Vol. 17, 00043. DOI: 10.1051/e3sconf/20171700043

11. Fidorów-Kaprawy N., Kostka M., Szulgowska-Zgrzywa M., Piechurski K. (2017). The energy concept of the building as a part of sustainable construction. Architectus, Vol. 49, No. 1, pp. 115-130. DOI: 10.5277/arc170108

12. Determination of the basic requirements necessary to achieve the expected energy standards for residential buildings and the method to verify designs and to check built energy-efficient homes [in Polish], National Fund for Environmental Protection and Water Management Warsaw, 2012.

13. Wysocka N., Michalak P., Grygierczyk S. (2017). Selected aspects of the exploitation of the mechanical air handling units in a low-energy building [in Polish]. Rynek Instalacyjny, Vol. 25, No. 12, pp. 48-51.

14. Michalak, P., Grygierczyk, S. (2015). Heat pumps in the passive office building: first exploitation results [in Polish]. Cieptownictwo Ogrzewnictwo Wentylacja, Vol. 46, No. 10, pp. 396-398.

15. Michalak P., Grygierczyk S. (2017). Temperature Efficiency of the Heat Recovery in an Air-Handling Unit with a Rotary Heat Exchanger [in Polish]. Cieptownictwo, Ogrzewnictwo, Wentylacja, Vol. 49, No. 5, pp. 183-187. DOI:0.15199/9.2018.5.4

16. PN-EN 308:2001 (2001). Heat exchangers. Test procedures for establishing the performance of air to air and flue gases heat recovery devices. Polish Committee for Standardization. Warszawa.

17. Asdrubali F., Baldinelli G., Bianchi F., Cornicchia M. (2015). Experimental Performance Analyses of a Heat Recovery System for Mechanical Ventilation in Buildings. Energy Procedia, Vol. 82, pp. 465-471. https://doi.org/10.1016/j.egypro.2015.11.845

18. Borowski M., Jaszczur M., Satoła D., Kleszcz S., Karch M. (2018). An analysis of the innovative exhaust air energy recovery heat exchanger. In: ICCHMT 2018, MATEC Web of Conferences, Vol. 240, 02003. DOI: $10.1051 /$ matecconf/201824002003

19. Regulation of the Minister of Infrastructure of April 12, 2002 on the technical conditions to be met by buildings and their location (Journal of Laws No. 75, item 690), as currently amended.

20. Kosieradzki J. (2009). Heat recovery - possibilities and principles [in Polish]. Rynek Instalacyjny, Vol. 17, No. 3, pp. 55-56.

21. Lipska B., Trzeciakiewicz Z., Ferdyn-Grygierek J., Popiolek Z. (2011). The Improvement of Thermal Comfort and Air Quality in the Historic Assembly Hall of a University. Indoor and Built Environment, Vol. 21, No. 2, pp. 332-347. DOI: 10.1177/1420326X11411244

22. Bareika P., Martinaitis V., Misevičiūtè V. (2012). Ventilation heat recovery using air source heat pump analyze. In: Inżynieria Środowiska - Młodym Okiem, Vol.1, pp. 175-178.

23. Georges L., Skreiberg Ø. (2014). Modeling of the Indoor Thermal Comfort in Passive Houses heated by Wood Stoves. In: 9th International Conference on System Simulation in Buildings, Liege, December 10-12, 2014.

24. Anisimov, S., Jedlikowski, A., Pandelidis, D. (2015). Frost formation in the cross-flow plate heat exchanger for energy recovery. International Journal of Heat and Mass Transfer, Vol. 90, pp. 201-217. DOI: 10.1016/j.ijheatmasstransfer.2015.06.056

25. Skrzycki M., Besler M. (2017). Impact of damper opening time on work of storage matrix regenerative heat exchanger. In: E3S Web of Conferences, Vol. 17, 00082. DOI: $10.1051 / \mathrm{e} 3 \operatorname{sconf} / 20171700082$
26. Jaszczur M., Kleszcz S., Borowski M. (2019). Analysis of the anti-icing system used in air handling units with a counterflow heat exchanger. In: E3S Web of Conferences, Energy and Fuels, Vol. 108, 01022. DOI: $10.1051 / \mathrm{e} 3$ sconf $/ 201910801022$

27. Hviid C.A., Svendsen S. (2011). Analytical and experimental analysis of a low-pressure heat exchanger suitable for passive ventilation. Energy and Buildings, Vol. 43, pp. 275-284. DOI: 10.1016/j.enbuild.2010.08.003

28. Pikas E., Thalfeldt M., Kurnitski J., Liias R. (2015). Extra cost analyses of two apartment buildings for achieving nearly zero and low energy buildings. Energy, Vol. 84, pp. 623-633. DOI: 10.1016/j.energy.2015.03.026

29. Frein A., Muschera M., Scoccia R., Aprile M., Motta M. (2018). Field testing of a novel hybrid solar assisted desiccant evaporative cooling system coupled with a vapour compression heat pump. Applied Thermal Engineering, Vol. 130, pp. 830-846. DOI: 10.1016/j.applthermaleng.2017.10.168

30. Nie J., Yuan S., Fang L., Zhang Q., Li D. (2018). Experimental study on an innovative enthalpy recovery technology based on indirect flash evaporative cooling. Applied Thermal Engineering, Vol. 129, pp. 22-30. DOI: 10.1016/j.applthermaleng.2017.09.139

\section{Biographical notes}

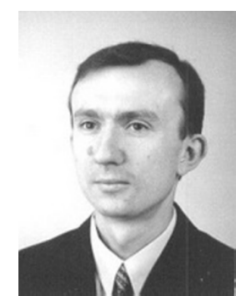

Piotr Michalak received Ph.D degree in Energy Machines and Equipment from AGH, Kraków. Since 2009 he has been a researcher in the Department of Power Systems and Environmental Protection Facilities at the AGH. His scientific interests focus on problems concerning energy modelling and thermal dynamics of buildings, utilisation of renewable energy sources, CFD simulations and thermal and flow measurements. He is the author or coauthor of 58 scientific papers.

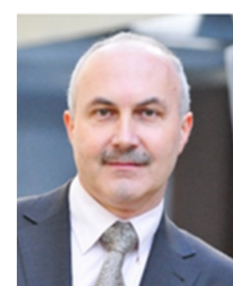

Stanisław Grygierczyk received Ph.D. degree from University of Silesia in Katowice. Since 2008, the scientific and environmental coordinator at the Euro-Centrum Science and Technology Park in Katowice, where the first office and service building in Poland in the passive standard was built. $\mathrm{He}$ specializes in issues related to increasing energy efficiency, especially in buildings, the use of energy from renewable sources, technologies for improving the energy efficiency of buildings, low-energy and passive buildings, prosumer energy based on renewable and distributed energy sources, formal, legal and economic aspects of renewable energy development. He also participated in the implementation of several scientific and research projects related to improving energy efficiency and increasing the use of renewable energy in buildings. 